\title{
GOSPODARKA INDII W WARUNKACH ŚWIATOWEGO KRYZYSU GOSPODARCZEGO. PERSPEKTYWY NA PRZYSZŁOŚĆ
}

Od kilku lat świat przeżywa jeden z najpoważniejszych kryzysów gospodarczych. Jego pierwsze symptomy odnotowano w 2006 roku, kiedy znacząco spadły ceny nieruchomości. Kolejnymi wydarzeniami były: bankructwo dwóch funduszy inwestycyjnych banku Bear Stearns i dokapitalizowanie głównych amerykańskich banków (m.in. Goldman Sachs, Morgan Stanley i Lehman Brothers). Zabieg ten przyniósł krótkotrwały efekt - 15 września 2008 roku upadł bank inwestycyjny Lehman Brothers, a w sektorze bankowym nastąpiły zwolnienia pracowników. Na wydarzenia te zareagowała branża motoryzacyjna: nastąpił spadek sprzedaży samochodów, co pociągnęło za sobą redukcję zatrudnienia i zamykanie wielu zakładów. Podobne problemy dotknęły także inne branże. Wiele państw doświadczyło recesji lub spowolnienia gospodarczego. Na światowych giełdach notowano spadki cen akcji, natomiast wielokrotnie wzrosła cena złota. Niektóre państwa członkowskie Unii Europejskiej znalazły się na krawędzi bankructwa i bardzo poważnie rozważano ich wyjście ze strefy euro. ${ }^{1}$ Jednakże, mimo swojego globalnego charakteru, kryzys ekonomiczny w różnym stopniu dotknął różne kraje. Jak się wydaje, podatność gospodarki danego państwa na kryzys uzależniona jest od bardzo wielu czynników i chyba trudno byłoby stworzyć jakiś jeden model. Inaczej kryzys przebiega

1 Problem światowego kryzysu gospodarczego doczekał się już obszernej literatury. W wielu publikacjach autorzy próbują znaleźć odpowiedź na pytanie, dlaczego doszło do tak poważnego załamania gospodarki światowej, próbują wskazać drogi wyjścia oraz przewidzieć, jakie będą konsekwencje kryzysu dla przyszłej polityki, gospodarki, a także społeczeństw. Z obszernej listy publikacji można wskazać chociażby na takie prace, jak: N. Roubini, S. Mihm, Crisis Economics: A Crash Course in the Future of Finance, Penguin Group, London 2011; M. Chossudovsky, A.G. Marshall, The Global Economic Crisis. The Great Depression of the XXI Century, Global Research, Montreal 2010; J. Bellamy Foster, F. Magdoff, The Great Financial Crisis: Causes and Consequences, Monthly Review Press, New York 2009; A. MacEwan, J.A. Miller, Economic Collapse, Economic Change: Getting to the Roots of the Crisis, M.E. Sharpe, Armonk 2011; J. Friedman, R.A. Posner, What Caused the Financial Crisis, University of Pennsylvania Press, Philadelphia 2010; P.D. Schiff, J. Downes, Crash Proof 2.0: How to Profit From the Economic Collapse, Wiley \& Sons, Hoboken 2011; M.N. Baily, D.J. Elliott, The US Financial and Economic Crisis: Where Does It Stand and Where Do We Go From Here?, Initiative on Business and Public Policy at Brookings, June 2009, http://www.brookings.edu/ /media/research/files/papers/2009/6/15\%20economic\%20crisis\%20 baily\%20elliott/0615_economic_crisis_baily_elliott; International Monetary Fund, World Economic and Financial Surveys, World Economic Outlook. Crisis and Recovery, Washington, April 2009, http://www. imf.org/external/pubs/ft/weo/2009/01/pdf/text.pdf 
w państwach europejskich, inaczej w Stanach Zjednoczonych, Kanadzie czy Japonii. Spore zainteresowanie wywołuje kwestia wpływu kryzysu na kraje charakteryzujące się szybkim wzrostem gospodarczym, takie jak Chiny. ${ }^{2}$ Dotyczy to również Indii, które w ostatnim dziesięcioleciu odznaczały się wzrostem gospodarczym sięgającym 9\% rocznie. Co zrozumiałe, reakcja gospodarki takiego kraju na światowy kryzys budzi zainteresowanie. ${ }^{3}$ Jednak ze względu na dynamizm światowego kryzysu gospodarczego i zmieniającą się kondycję gospodarki indyjskiej warto po raz kolejny spojrzeć na jej stan i spróbować odpowiedzieć na pytanie, w jakim stopniu jest podatna na zawirowania w świecie międzynarodowej gospodarki, jak sobie z nimi radzi i co może z tego wyniknąć w najbliższych latach.

Pisząc o gospodarce indyjskiej, jak i w ogóle o Indiach, trzeba poczynić pewne istotne zastrzeżenie, że mówi się o całości, a nie o poszczególnych stanach, ${ }^{4}$ że próbuje się stworzyć zgeneralizowany obraz. Jak bardzo zróżnicowane są Indie, świadczyć może chociażby dysproporcja w zaludnieniu poszczególnych stanów - w najludniejszym, Uttar Pradesh, mieszka 199581477 osób, a w Lakszadiwy (Lakkadiwy) 64429 osób, ${ }^{5}$ czy też tempo rozwoju: stany takie jak Bihar, Orissa i Chhattisgarh w latach 2004-2009 rozwijały się szybciej niż wynosiła średnia krajowa. ${ }^{6}$

Do 1991 roku gospodarka indyjska miała charakter socjalistyczny, gdyż taki model przyjęto po uzyskaniu niepodległości w 1947 roku. Był on oparty na samowystarczalności i dominacji sektora publicznego, a jednym z celów polityki była likwidacja ubóstwa. ${ }^{7}$ Wobec kryzysu, który dotknął gospodarkę w 1966

2 Więcej na ten temat patrz: N.R. Lardy, Sustaining China's Economic Growth after the Global Financial Crisis, Peter G. Peterson Institute for International Economics, Washington 2012; China and the Global Economic Crisis, red. Zheng Yongnian, S.Y. Tong, „Series on Contemporary China” Vol. 22, World Scientific Publ. Co., Singapore 2010; China's Crisis Management, red. Jae Ho Chung, Routledge, London-New York 2012.

3 Znalazło to odzwierciedlenie w pojawiających sie publikacjach. Patrz np.: A. Kishore, M. Debabrata Patra, P. Ray, The Global Economic Crisis through an Indian Looking Glass, Sage Publ. India, New Delhi 2011; Global Economic Crisis and Impact on India Economy, red. A. Kumar Thakur, D. Taneja, Deep \& Deep Publ., New Delhi 2011; Global Meltdown and India Economy, red. A. Kumar Thakur, P. Singh, Deep \& Deep Publ., New Delhi 2011; Y. Venugopal Reddy, India and the Global Financial Crisis. Managing Money and Finance, Anthem Press, London 2011; Global Recession and India Economic Development, red. S. Asokkumar, New Century Publ., New Delhi 2010.

4 Terytorium Indii podzielone jest na 28 stanów i 7 zjednoczonych terytoriów. Library of Congress, Federal Research Division, Country Profile: India, December 2004, s. 16, http://lcweb2.loc.gov/frd/cs/ profiles/India.pdf

5 Government of India, Ministry of Home Affairs, Office of the Register General \& Census Commissioner, Provisional Population Totals Paper 1 of 2011 India, s. 47.

6 Bihar - 12,4\%, Orissa - 10,2\% i Chhattisgarh - 9,7\%. T. Cukiernik, Indie. Gospodarczy tygrys dzięki reformom wolnorynkowym, „Najwyższy Czas” 18 września 2011.

7 S. Staley, The Rise and Fall of Indian Socialism. Why India Embraced Economic Reform, „Reason.com” June 2006, http://reason.com/archives/2006/06/06/the-rise-and-fall-of-indian-so; A. Panagariya, India: The Emerging Giant, Oxford University Press, New York, s. 24, 31-32; T. Cukiernik, op.cit. 
roku, podjęto próbę jej zreformowania, ale z pomysłu wycofano się w 1967 roku. Ponowną próbę zreformowania systemu gospodarczego poprzez liberalizację podjęto w 1985 roku, ale podobnie jak przy wcześniejszej wycofano się z niej w 1987 roku. ${ }^{8}$ W 1991 roku, pod naciskiem Międzynarodowego Funduszu Walutowego, rząd indyjski zdecydował się na reformy ze względu na poważny kryzys ekonomiczny. ${ }^{9}$ Celem reform było przejście do systemu kapitalistycznego, wzrostu gospodarczego $\mathrm{i}$ industrializacji. ${ }^{10} \mathrm{~W}$ ramach zmian państwo $\mathrm{m}$.in. zrezygnowało $\mathrm{z}$ kontroli wymiany walut, obniżono cła, zliberalizowano sektor finansowy, zmniejszono dotacje do paliw i ułatwiono inwestycje zagraniczne. ${ }^{11}$ Jak zauważa Katarzyna Hołdak, wprowadzając reformy gospodarcze, Indie wybrały inny wariant niż kraje tego regionu. Zamiast oparcia zmian na eksploatacji taniej siły roboczej i niskich kosztach produkcji zdecydowano się na rozwój rynku wewnętrznego, wzrost konsumpcji wewnętrznej oraz inwestowanie w dynamicznie rozwijające się i przyszłościowe branże, takie jak informatyka czy biotechnologia. ${ }^{12}$

Wprowadzone reformy spowodowały, że gospodarka Indii stała się jedną z najszybciej rozwijających się na świecie. Już w pierwszych latach, 1994-1997, po wprowadzeniu reform wzrost gospodarzy wyniósł $7,5 \% .{ }^{13} \mathrm{~W}$ ostatnim dziesięcioleciu PKB Indii wzrastał średnio 8,5\% rocznie. ${ }^{14} \mathrm{~W} 2011 \mathrm{roku}^{15}$ Indie zajmowały dziesiąte miejsce na świecie, uwzględniając nominalny PKB, i czwarte, biorąc pod uwagę parytet siły nabywczej. Nominalny PKB wyniosł 1843 mld dol., PKB per capita w 2011 roku - 3608196 dol., wzrost PKB - 7,8\% (na 2012 rok prognozowane było 6,5-8,4\%). ${ }^{16}$ Prognozy te ulegały zmianie w zależności od informacji napływających z Indii i miały

8 Ch. Kumar Sharma, A Discursive Dominace Theory of Economic Reform Sustainability: The Case of India, Munich Personal RePEc Archive, January 2008, s. 5-8, http://mpra.ub.uni-muenchen.de/31001/1/ MPRA_paper_31001.pdf

9 B. Weinraub, Economic Crisis Forcing Once Self-Reliant India to Seek Aid, „The New York Times” June 29, 1991, http://www.nytimes.com/1991/06/29/world/economic-crisis-forcing-once-self-reliantindia-to-seek-aid.html

10 Th. Nilakanta Srinivasan, S.D. Tendulkar, Reintegrating India with the World Economy, Institute for International Economics, Washington 2003, s. 1-26.

11 T. Cukiernik, op.cit.

${ }^{12}$ K. Hołdak, Indie - nowe mocarstwo?, „Bezpieczeństwo Narodowe” 2006, nr 2, s. 139-140.

13 T. Cukiernik, op.cit.

142008 - 6,2\%, 2009 - 7,2\%, 2010 - 10,12\%, 2011 - 7,8\%. Ministerstwo Gospodarki, Notatka o stosunkach gospodarczych Polski z Indiami, http://www.mg.gov.pl/node/7266

15 Indyjski rok podatkowy trwa od 1 kwietnia do 31 marca.

16 International Monetary Fund, World Economic Outlook Database, April 2011, India, http:// www.imf.org/external/pubs/ft/weo/2011/01/weodata/weorept.aspx?sy $=2008 \&$ ey $=2011 \&$ scsm $=1$ $\& \mathrm{ssd}=1 \&$ sort $=$ country \&ds $=. \& \mathrm{br}=1 \& \mathrm{c}=534 \& \mathrm{~s}=\mathrm{NGDPD} \% 2 \mathrm{CNGDPDPC} \% 2 \mathrm{CPPPGDP} \% 2 \mathrm{CPPP}$ PC\%2CLP\&grp=0\&a=\&pr.x=49\&pr.y=13; GDP Growth at 5.3\% for Q\$, Slowest in 9 Years, „The Economic Times" May 31, 2012, http://articles.economictimes.indiatimes.com/2012-05-31/news/ 31921922_1_gdp-growth-cent-expansion-cent-growth 
wydźwięk raczej pesymistyczny. ${ }^{17}$ Jednak najnowsze dane wydają się być bardziej optymistyczne, gdyż przewidują wzrost PKB na poziomie $5,5 \% .{ }^{18}$

Największy udział w tworzeniu PKB ma sektor usług, który w Indiach obejmuje szerokie spektrum działalności od zaawansowanej $\mathrm{IT}^{19}$ do prostych usług typu fryzjerstwo i wynosi on 59\%. ${ }^{20} \mathrm{~W} 2010$ roku wartość wyeksportowanych usług wyniosła 3695 mld dol. ${ }^{21}$ Do sektora usług zalicza się m.in. budownictwo, handel, hotelarstwo, transport i komunikację, finanse, ubezpieczenia, obrót nieruchomościami, usługi biznesowe. W tym obszarze największy, bo 16,9\% udział mają handel, hotelarstwo i gastronomia. Drugi, 16,4\% udział należy do sektora usług finansowych, ubezpieczeniowych, biznesowych i nieruchomości, a trzeci, z 14,3\%, - do sfery socjalnej. ${ }^{22}$ Sektor usług zajmuje drugie miejsce (po rolnictwie) jeżeli chodzi o zatrudnienie około 34\% pracujących. Szacuje się, że na 1000 Hindusów na wsi i w mieście w usługach znajdują zatrudnienie odpowiednio 241 i 683 osoby. ${ }^{23}$

Drugie miejsce w tworzeniu PKB Indii zajmuje przemysł z 27\% udziałem. ${ }^{24}$ Przemysł $\mathrm{w}$ Indiach to przede wszystkim przemysł tekstylny, telekomunikacyjny, ${ }^{25}$ chemiczny, spożywczy, stalowy, samochodowy, ${ }^{26}$ cementowy, wydobywczy, petrochemiczny, maszynowy, farmaceutyczny, produkcja komputerów i oprogramowania.

17 India's Slowdown. Stopping the Spiral, „,The Economist” June 11, 2012, http://www.economist.com/ blogs/banyan/2012/06/indias-slowdown?zid=309\&ah=80dcf288b8561b012f603b9fd9577f0e; Farewell to Incredible India, ,,The Economist” June 9, 2012, http://www.economist.com/node/21556576?zid=309\&ah= 80dcf288b8561b012f603b9fd9577f0e

18 Is this the Bottom?, „The Economist” August 31, 2012, http://www.economist.com/blogs/banyan/ 2012/08/indias-economy?zid=309\&ah=80dcf288b8561b012f603b9fd9577f0e

19 Na temat rozwoju branży IT w Indiach patrz: S.V. Nagala, India's Story of Success, „Stanford Journal of International Relations" Winter 2005, Vol. 6, Issue 1, http://www.stanford.edu/group/sjir/6.1.05_ nagala.html

20 Government of India, Ministry of Finance, Economic Survey, 2011-12, Table 1.6: Sectoral Composition of GDF, s. 8, http://indiabudget.nic.in/survey.asp

21 Ibidem, s. 227.

22 Budownictwo ma 8,2\% udział, a transport i komunikacja 7,7\%. Government of India, Ministry of Finance, Economic Survey, 2011-12, Table 10.2: Share of different service categories in GDP at factor cost (current prices), s. 228, http://indiabudget.nic.in/survey.asp

${ }^{23}$ Ibidem, s. 231.

24 Ibidem, s. 8.

25 Ta branża uznawana jest za jedną z najszybciej rozwijających się - tylko w 2010 roku przybyło 227 mln abonentów. Telecom Regulatory Authority of India, Information Note to the Press (Press Release No. 29/2011), New Delhi, April 6, 2011, http://www.trai.gov.in/WriteReadData/trai/upload/PressReleases/816/ Press_release_feb\%20-11.pdf

${ }^{26}$ Indyjski przemysł samochodowy zajmuje drugie miejsce na świecie pod względem tempa wzrostu. Sprzedaż samochodów na rynku wewnętrznym wzrosła w latach 2009-2010 o 26\%, a eksport w okresie 2008-2009 o 36\%. Niemały udział ma w tym najtańszy samochód świata Nano produkowany przez Tata Motors. J. Krishnan, The Nano, World's Cheapest Car, to Hit Indian Roads, Reuters, March 23, 2009, http://www.reuters.com/article/2009/03/23/us-tatamotors-nano-idUSTRE52M2PA20090323; India becomes Biggest Player in Littlest Cars, December 27, 2009, msnbc.com, http://www.msnbc.msn. com/id/34575226/ns/business-autos\#.TnCQk2PXQsY; India Second Fastest Growing Auto Market After China, The Hindu Business Line, April 9, 2010, http://www.thehindubusinessline.com/todays-paper/ 
Niezwykle istotnym obszarem rozwijanym w Indiach, z którym wiąże się nadzieje na przyszłość, jest biotechnologia i nanotechnologia. ${ }^{27}$ Kraj ten zajmuje dwunaste miejsce na świecie pod względem rozwoju biotechnologii (i trzecie w Azji), a sektor ten odnotował 21,5\% wzrostu w latach 2010-2011. Przyniósł on znaczne zyski - 4 mld dol. obecnie, a przyszłe szacowane są na 10 mld w 2015 roku. ${ }^{28}$

Przemysł zatrudnia około $21,9 \%$ czynnych zawodowo, co daje ponad $100 \mathrm{mln}$ osób. ${ }^{29} \mathrm{Na}$ każde 1000 Hindusów mieszkających na wsi i w mieście odpowiednio 80 i 242 znajduje zatrudnienie w przemyśle. ${ }^{30}$

Szczególne miejsce zajmuje przemysł tekstylny, który tworzy 20\% całości produkcji przemysłu indyjskiego i zatrudnia ponad 20 mln pracowników. ${ }^{31}$ Przemysł tekstylny ma także znaczący udział w indyjskim eksporcie. W roku rozliczeniowym 2010-2011 eksport indyjskich tekstyliów i ubrań osiągnął wartość 26,8 mld dol. (w roku rozliczeniowym 2009-2010 było to 22,4 mld dol.). W skali światowej, jako eksporter gotowych ubrań, Indie zajmują szóste miejsce po Turcji, Bangladeszu, Hongkongu, Unii Europejskiej i Chinach, a trzecie jako eksporter tkanin po Unii Europejskiej i Chinach. ${ }^{32}$

Tak mocna pozycja branży tekstylnej jest wynikiem m.in. polityki prowadzonej przez władze państwowe, które w latach 2004-2005 zniosły wiele ograniczeń dotyczących przemysłu tekstylnego. Efektem tego był znaczący napływ środków finansowych (w latach 2004-2008 było to 27 mld dol.) zarówno ze źródeł wewnętrznych, jak i zewnętrznych. ${ }^{33}$ Pozycja ta może jeszcze ulec wzmocnieniu w najbliższych latach, gdyż wobec objawów recesji władze Indii podejmują różnorakie działania, by zaradzić temu zjawisku. Jest to m.in. zapewnienie dopływu dalszych środków finansowych, tworzenie nowych miejsc pracy (ponad $17 \mathrm{mln}$ ), wspieranie eksportu oraz pozyskiwanie nowych i rozszerzanie istniejących rynków dla indyjskiej produkcji tekstylnej. ${ }^{34}$

Trzecie miejsce w tworzeniu PKB w Indiach zajmuje rolnictwo z udziałem 13,9\% PKB. Daje ono zatrudnienie około $44 \%$ czynnych zawodowo. ${ }^{35}$ Rolnictwo to przede

article988689.ece?ref=archive; Indian Car Exports Surge 36\%, expressindia.com, October 13, 2009, http:// www.expressindia.com/latest-news/Indian-car-exports-surge-36/528633/

$27 \mathrm{Na}$ temat przemian zachodzących w gospodarce indyjskiej patrz np. J. Dhawan, The Changing Face of Indian Economy, Atlantic, New Delhi 2007.

28 India Brand Equity Foundation, Biotechnology, August 2011, http://www.ibef.org/industry/ biotechnology.aspx

${ }^{29}$ Government of India, Ministry of Finance, Economic Survey, 2011-12, op.cit., s. 202.

30 Ibidem, s. 231.

31 R. Datt, K.P.M. Sundharam, Indian Economy, Niraj Prakashan, New Delhi 2009, s. 646.

32 Government of India, Ministry of Finance, Economic Survey, 2011-12, op.cit., s. 217.

33 Dark Clouds prevailing on the Indian Textile Industry, The Textile Icon, July 19, 2011, http://www. thetextileicon.com/blog/2011/07/19/dark-clouds-prevailiing-on-the-indian-textile-industry/

${ }^{34}$ Government of India, Ministry of Finance, Economic Survey, 2011-12, op.cit., s. 218.

35 Ibidem, Table 1.6: Sectoral Composition of GDF, op.cit., s. 8. 
wszystkim uprawa ryżu, ${ }^{36}$ świeżych owoców (około 10\% udział w rynku światowym), bawełny, herbaty, kawy, ${ }^{37}$ cukru, ziemniaków, nabiału, tytoniu i pomidorów. ${ }^{38}$

Podstawowym zadaniem rolnictwa indyjskiego jest $\mathrm{z}$ jednej strony zapewnienie wyżywienia obywatelom, ${ }^{39} \mathrm{z}$ drugiej zaś zagwarantowanie rolnikom zysków z eksportu. W 2010 roku Indie wyeksportowały produkty rolne o wartości 23,2 mld dol., co dawało im 15 miejsce na świecie. Import produktów rolnych do Indii w 2010 roku wyniósł 15,5 mld dol. ${ }^{40}$

Indie stanowią interesujące miejsce dla bezpośrednich inwestycji zagranicznych. ${ }^{41}$ Decydują o tym takie czynniki, jak dogodne warunki inwestycyjne wyrażające się m.in. zniesieniem różnego rodzaju ograniczeń, tanią siłą roboczą, dużym rynkiem zbytu. ${ }^{42} \mathrm{~W}$ ostatnich latach do Indii napłynęly znaczne fundusze: $\mathrm{w} 2006 \mathrm{roku}$ - 20328 mln dol.; w 2007 roku - 25506 mln dol.; w 2008 roku - 43406 mln dol.; w 2009 roku - 35596 mln dol.; w 2010 roku - 24159 mln dol.; w 2011 roku - 31554 mln dol. ${ }^{43}$ Co ważniejsze, nawet kryzys w gospodarce światowej nie zniechęcił do

36 Indie, z produkcją 99 tys. t, zajmują drugie miejsce, po Chinach, na świecie. World Rice Production, Consumption, and Stocks, July 15, 2010, http://news.alibaba.com/article/detail/international-tradespecial/100360611-1-world-rice-production\%252C-consumption\%252C-stocks.html

37 Według danych dla 2011 roku Indie zajmują trzecie miejsce jako eksporter kawy. Na pierwszym miejscu znalazła się Brazylia z 2032693 t, na drugim Wietnam z 1200 000, a na trzecim Indie z 468603 t. International Coffee Organization, Exports by Exporting Countries to All Destinations, July 2011, http:// www.ico.org/prices/m1.htm

$38 \mathrm{Na}$ temat udziału Indii w światowej produkcji rolnej patrz: United States, Department of Agriculture, World Agricultural Production, May 2010, http://www.fas.usda.gov/wap/circular/2010/10-05/ productionfull05-10.pdf

39 By osiągnąć ten cel, w 1965 roku rozpoczęto „zieloną rewolucję”. Poprzez wprowadzenie wysoko wydajnych upraw, rozpowszechnienie używania nawozów i rozbudowę systemów irygacyjnych poprawiono kondycję rolnictwa. „Zielona rewolucja” zlikwidowała wprawdzie problem głodu w Indiach, ale nie rozwiązała problemu niedożywienia, które szczególnie dotyka dzieci. Według szacunków w 2008 roku w Indiach było niedożywionych około 48\% dzieci poniżej 5 roku życia, co lokowało ten kraj na drugim miejscu po Etiopii (Gothekar Pada, Putting the Smallest First, „The Economist” September 23, 2010, http://www.economist.com/node/17090948). Na temat „zielonej rewolucji” patrz np.: R.N. Chopra, Evolution of Food Policy in India, Macmillan, Delhi 1981; The Green Revolution Revisited. Critique and Alternatives, red. B. Glaeser, Allen \& Unwin, London 1987; B. Venkateswarlu, Dynamics of Green Revolution in India, Agricole Publ. Academy, New Delhi 1985; W. Rozłucki, Modernizacja rolnictwa tradycyjnego na przykładzie zielonej rewolucji w Indiach, Zakład Narodowy im. Ossolińskich, Wrocław 1979.

40 Government of India, Ministry of Finance, Economic Survey, 2011-12, s. 186, op.cit.

41 Szczegółowa analiza zjawiska bezpośrednich inwestycji zagranicznych w Indiach została zawarta w rozprawie doktorskiej S. Hooda, A Study of FDI and India Economy, złożonej w Department of Humanities and Social Sciences, National Institute of Technology, Deemed University w styczniu 2011, http://www.nitkkr.ac.in/Sapna_Hooda_Thesis_A_Study_of_FDI_and_Indian_Economy.pdf

42 Rynek wewnętrzny w Indiach lokowany jest na czwartym miejscu pod względem atrakcyjności wśród rynków wschodzących. A.T. Kearney, Global Retail Development Index, 2011, http://www.atkearney. com/index.php/Publications/global-retail-development-index.html

${ }^{43}$ United Nations Conference on Trade and Development UNCTAD, World Investment Report 2012. Towards a New Generation of Investment Policies, Annex Table I.1: FDI flows, by region and economy, 2006-2011, s. 171, http://www.unctad-docs.org/files/UNCTAD-WIR2012-Full-en.pdf 
inwestowania w Indiach. Początek roku 2012 przyniósł przejściowe ograniczenie w zagranicznych inwestycjach, ale już od kwietnia 2012 roku zanotowano napływ 5 mld dol. inwestycji. ${ }^{44}$

W Indiach inwestuje wiele znanych firm reprezentujących bardzo różne sektory. Można tu wspomnieć chociażby o przedstawicielach branży samochodowej, takich jak Suzuki, ${ }^{45}$ Hyundai, ${ }^{46}$ Ford, ${ }^{47}$ Renault, ${ }^{48}$ Nissan, ${ }^{49}$ Rolls Royce, ${ }^{50}$ Ferrari (na razie firma ograniczyła się do otwarcia swoich salonów w Indiach), ${ }^{51}$ Fiat, Audi i Volkswagen, ${ }^{52}$ przemysłowej, jak Bosch, ${ }^{53}$ czy farmaceutycznej, np. Daiichi Sankyo z Japonii ${ }^{54}$, Abbott Labs czy Pfizer. ${ }^{55}$ Takie firmy, jak Ikea czy Wal-Mart otwierają swoje sklepy, ${ }^{56}$ a np. Coca-Cola decyduje się na zainwestowanie w Indiach $5 \mathrm{mld}$ dol. w ciągu ośmiu lat. ${ }^{57}$

44 They Just Keep on Keeping on. Against All the Odds Foreign Investors Continue to Pile into India. Why?, ,The Economist” September 8, 2012, http://www.economist.com/node/21562227

${ }^{45}$ Interesująca analiza dotycząca obecności firmy Suzuki na indyjskim rynku znajduje się w: A.K.J.R. Nayak, FDI Model in Emerging Economies: Case of Suzuki Motor Corporation in India, „The Journal of American Academy of Business" March 2005, s. 238-245, http://www.ximb.ac.in/ jcr/Suzuki.pdf

${ }^{46}$ Hyundai zajmuje drugie miejsce po Suzuki w produkcji samochodów w Indiach.

47 Firma Ford jest zainteresowana zwiększaniem swojej produkcji w Indiach. Planuje się, że w 2014 roku, kiedy zakończone zostaną realizowane inwestycje, produkcja osiągnie wielkość 610 tys. silników i 440 tys. pojazdów rocznie. Sh. Chopra, Ford's India Story: Successes and Challenges, „Rediff Business” May 7, 2012, http://www.rediff.com/business/slide-show/slide-show-1-interview-fords-india-storysuccesses-and-challenges/20120507.htm

48 Renault in India, http://www.renault.com/en/groupe/renault-dans-le-monde/pages/renault-eninde.aspx

$49 \mathrm{http}: / /$ www.nissan.in/en/web/header/header_4385.htm

$50 \mathrm{http}: / /$ www.rolls-royce.com/india/in/about/rolls_royce_india.jsp

51 Ferrari officially debuts in India, http://www.ferrari.com/english/about_ferrari/corporate/ pages/110526_cor_ferrari_officially_debuts_in_india.aspx

52 D. Grądzka, Rozwój Indii a bezpośrednie inwestycje zagraniczne - czy Indie to miejsce gdzie warto inwestować?, Centrum Studiów Polska-Azja, 5 grudnia 2009, http://www.polska-azja.pl/2009/12/05/ rozwoj-indii-a-bezposrednie-inwestycje-zagraniczne-czy-indie-to-miejsce-gdzie-warto-inwestowac/; Ministerstwo Gospodarki, Notatka o stosunkach gospodarczych Polski z Indiami, http://www.mg.gov.pl/ node/7266

53 Bosch ma w Indiach, największe po Niemczech, centrum badawcze. http://www.boschindia.com/ content/language $1 / \mathrm{html} / 7310$.htm

54 Daiichi Sankyo India Pharma Pvt. Ltd., http://www.dsin.co.in/

55 Firma ta została uznana za najlepsze miejsce pracy w Indiach. Pfizer India Has been Recognized as one of ,,The Best Companies to Work For" by Business Today magazine, http://www.pfizerindia.com/ enewswebsite/bestc.aspx

${ }^{56}$ Ikea zdecydowała się na taki krok po zmianie przepisów w Indiach. W listopadzie 2011 roku władze w New Delhi przyjęły regulację, która pozwala zagranicznym firmom na otwieranie należących do nich oddziałów, jeśli posiadają jedną markę. Natomiast w przypadku międzynarodowych koncernów mogą one posiadać $51 \%$ udziałów w sieciach handlowych, które sprzedają towary wielu marek. Wal-Mart będzie mógł wejść do Indii. Rzad zaprasza hipermarkety, „Gazeta Wyborcza” 24 listopada 2022; Ikea otworzy 25 sklepów w Indiach, zainwestuje ponad miliard dolarów, „Gazeta Wyborcza” 22 czerwca 2012.

57 Coca-Cola zwiększa inwestycje w Indiach. 5 mld dolarów w ciagu 8 lat, "Gazeta Wyborcza” 27 czerwca 2012. 
Będąc krajem przyjmującym bezpośrednie inwestycje zagraniczne, Indie inwestują także poza granicami. Jak zauważa Janusz Brzozowski z Pracowni Badań Rynków Zagranicznych, „[...] firmy chińskie chcą stać się »fabrykami świata «, wytwarzając produkty w kraju, to przedsiębiorstwa indyjskie starają się być aktywne i fizycznie obecne za granicą w postaci firm ponadnarodowych" ${ }^{58}$ Firmy o indyjskim rodowodzie inwestują w różnych branżach w wielu państwach świata. Koncern Tata Steel przejął brytyjsko-holenderski koncern stalowy Corus. Grupa Aditya Birla ${ }^{59}$ wykupiła firmę Novellis z branży aluminiowej. Koncern Tata Motors wykupił Jaguara i Land Rovera. W Polsce indyjska firma Essel Propack ${ }^{60}$ wybudowała w Kostrzyńsko-Słubickiej Specjalnej Strefie Ekonomicznej fabrykę opakowań kosmetycznych, a firma UFLEX wybudowała w Specjalnej Strefie Ekonomicznej we Wrześni fabrykę opakowań plastikowych. ${ }^{61}$ Ponad 100 przedsiębiorstw utworzonych przy indyjskim udziale działa w Malezji, w szesnastu państwach afrykańskich indyjska firma Bharti Airtel wykupiła firmy telekomunikacyjne, ${ }^{62}$ a w Etiopii Hindusi inwestują w rolnictwo ekologiczne. ${ }^{63}$ Koncerny indyjskie nabywają aktywa australijskich firm związanych z górnictwem węglowym - np. w maju 2011 roku firma Adani Enterprises (największy importer węgla w Indiach) przejęła, za 2 mld dol. australijskich, terminal węglowy Abbot Point w stanie Queensland. ${ }^{64}$ Ze strony państw południowoamerykańskich płyną zachęty, by indyjskie firmy inwestowały w ich gospodarki. Na przykład Wenezuela proponuje inwestowanie w sektor paliwowy, a Brazylia w farmaceutyczny i cukrownictwo. ${ }^{65} \mathrm{~W}$ Ameryce Łacińskiej obecne są takie indyjskie firmy, jak Godrej, Jindal Steel, Shree Renuka Sugar, Infosys, Wipro, Mahindra\&Mahindra,

58 J. Brzozowski, Przestarzałe struktury w gospodarce Indii blokuja jeszcze szybszy rozwój, Obserwator finansowy.pl, 11 marca 2012, http://www.obserwatorfinansowy.pl/forma/analizy/przestarzale -struktury-w-gospodarce-indii-blokuja-jeszcze-szybszy-rozwoj/

59 Więcej na temat firmy patrz: http://www.adityabirla.com/the_group/index.htm

60 Więcej na temat Essel Propack patrz: http://www.esselpropack.com/

${ }^{61}$ Ministerstwo Gospodarki, Notatka o stosunkach..., op.cit.

62 Więcej na temat działałności Bharti Airtel patrz: Bharti Airtel Limited, Quarterly Report on the Results for the Third Quarter and Nine Month Ended December 31, 2011, http://www.airtel.in/Quarterly Result/Quarterly_report_Q3_11.pdf

63 T. Cukiernik, op.cit., J.D. Pedersen, The Second Wave of Indian Investments Abroad, „Journal of Contemporary Asia" November 2008; Vol. 38, No. 4, India Brand Equity Foundation, Indian Investment Abroad, http://www.ibef.org/artdispview.aspx?in=37\&art_id=31604\&cat_id=599\&page=1; India Invests Abroad, „Forbes” November 23, 2011, http://www.forbes.com/2011/11/23/forbes-indiaentrepreneurs-invest-abroad.html; Overseas Indian Facilitation Centre, http://m.oifc.in/search? ArticleKeyword=Indian\%20investments\%20abroad

64 Indie oferuja Australii obiecujący rynek zbytu źródeł energii, Obserwator finansowy.pl, 11 lipca 2012, http://www.obserwatorfinansowy.pl/forma/analizy/indie-oferuja-australii-obiecujacy-rynek -zbytu-zrodel-energii/

65 India Brand Equity Foundation, India Investment Abroad, August 2012, http://www.ibef.org/india/ economy/indianinvestmentsabroad.aspx 
Suzlon i TCS. Szacuje się, że w lipcu 2012 roku indyjskie bezpośrednie inwestycje zagraniczne wyniosły $1,24 \mathrm{mld} \mathrm{dol} .{ }^{66}$

Podobnie jak wiele gospodarek państw, także indyjska odczuła skutki światowego kryzysu gospodarczego. Jednak, jak się wydaje, są one mniejsze niż w przypadku innych krajów. Niewątpliwym objawem związanym z kryzysem jest niższe niż zakładano PKB. Jest to skutek spowolnienia w górnictwie, rolnictwie i krajowym sektorze wytwórczym. W górnictwie wzrost ma wynieść 2,2\% (w 2010-2011 - 5\%), w rolnictwie 2,5\% (w 2010-2011 - 7\%), a w produkcji 3,9\% (w 2010-2011 - 7,5\%). ${ }^{67}$ Jednocześnie władze Indii podejmowały i podejmują działania, których celem jest przeciwdziałanie zjawiskom kryzysowym. W czynionych zabiegach w jakimś stopniu brane są pod uwagę sugestie płynące z kręgów akademickich. Podczas międzynarodowej konferencji „Post Economic Meltdown Era - Challenges and Strategies", która odbyła się w lutym 2012 roku, profesor Asim Kumar Mishra powiedział: „Musimy zredukować zadłużenie w stosunku do PKB i więcej zainwestować w żywotne sektory, takie jak rolnictwo i infrastruktura, by pobudzić gospodarkę. Dodatkowo powinniśmy poprawić nadzór i regulacje na poziomie mikro, by lepiej wykorzystać zasoby krajowe. [...] Indie powinny zainwestować w produkcję tanich i małych samochodów, kreując popyt oraz generując zyski poprzez eksport. Podobnie powinniśmy zezwolić na bezpośrednie inwestycje zagraniczne $\mathrm{w}$ handlu, ${ }^{68}$ by stały się one bodźcem dla gospodarki. [...] Powinniśmy wprowadzić systematyczną kontrolę ryzyka, a także obniżyć oprocentowanie pożyczek na potrzeby mieszkaniowe. Musimy przyjąć inny model gospodarowania i zarządzania oparty na potrzebach kraju, a nie naśladować Zachodu w wychodzeniu z kryzysu".69

W styczniu 2012 roku premier Singh spotkał się z szefami 26 państwowych firm $^{70}$ - szefowie $17 \mathrm{z}$ nich otrzymali od premiera osobiste polecenie zainwestowania

66 Ibidem.

67 Indie zweryfikowaly wstępne prognozy dotyczace wzrostu PKB kraju w roku obrachunkowym 2011-2012, „Rzeczpospolita” 7 lutego 2012.

68 Jest to kwestia dość delikatna. O ile bezpośrednie inwestycje zagraniczne raczej nie wywołują sprzeciwu, to jednak w dwóch sektorach odezwały się głosy niepokoju. Jednym jest sektor bankowości, którego pracownicy sprzeciwiają się wpuszczeniu do niego obcego kapitału w obawie o utratę miejsc pracy. Drugi sektor, a właściwie grupę, stanowią drobni właściciele sklepów, którzy obawiają się pełnego wejścia na rynek dużych sieci hipermarketów. Strajk bankowców w Indiach. Przyłaczyło się już milion osób, Money.pl, 22 sierpnia 2012, http://www.money.pl/banki/wiadomosci/artykul/strajki;bankowcow;w;ind iach;przylaczylo;sie;do;nich;juz;milion;osob,158,0,1146014.html; Wal-Mart będzie mógł wejść do Indii. Rząd zaprasza hipermarkety, „Gazeta Wyborcza” 24 listopada 2011.

69 Varanasi, Crisis is Blessing in Disguise for Small Industries: Expert, „Times of India” February 5, 2012, http://articles.timesofindia.indiatimes.com/2012-02-05/varanasi/31026933_1_subprime -crisis-eurozone-crisis-economic-reforms

70 W Indiach własnością państwa jest ponad 500 wielkich przedsiębiorstw, których łączna wartość szacowana jest na 500 mld dol. J. Brzozowski, op.cit. 
$\mathrm{w}$ infrastrukturę $\mathrm{w}$ sumie $35 \mathrm{mld}$ dol. $\mathrm{z}$ rezerw finansowych. ${ }^{71}$ Poza wszystkim innym, krok taki ma zachęcić prywatne firmy do inwestowania. Innym posunięciem rządu w New Delhi jest dawanie pierwszeństwa w dostępie do kapitału gospodarce, a nie bankom. ${ }^{72}$

Kolejnym elementem działań antykryzysowych, a sugerowanych przez naukowców, jest rozwijanie oszczędnej produkcji, a więc towarów tańszych o $50-90 \%$ niż te wytworzone w Europie czy Stanach Zjednoczonych. Przykładem może być samochód Nano produkowany przez koncern Tata, który kosztuje 2,5 tys. dol. Urzeczywistniając ideę oszczędności, Indie świadczą także dużo tańsze usługi - operacja serca czy oczu jest ponad 20 razy tańsza, a połączenie telefoniczne kosztuje 2 centy za minutę. ${ }^{73}$ Podobnie rzecz ma się z szerszym dostępem do indyjskiego handlu - przyjęte w listopadzie 2011 roku rozwiązania szerzej otworzyły rynek. ${ }^{74}$

Nie do przecenienia z punktu widzenia walki z kryzysem jest indyjska demografia. Należy tutaj zwrócić uwagę na dwa elementy. Jednym jest potencjał demograficzny, a drugim, powiązanym z pierwszym, diaspora indyjska. Indie należą do grupy najludniejszych państw świata i zajmują drugie miejsce po Chinach. Według danych z 2011 roku żyło tam 1210193422 osób, co stanowiło 17,47\% mieszkańców globu. ${ }^{75} \mathrm{~W}$ porównaniu z 2001 rokiem, kiedy w Indiach mieszkało 1028737436 osób, oznaczało to wzrost o $181 \mathrm{mln}$ w ciągu dekady. ${ }^{76}$

Przyrost naturalny w Indiach kształtuje się na poziomie 20,97 urodzeń na 1000 osób (2011), co daje 1,34\% rocznie (2011). Dzietność wynosi 2,62 dziecka na kobietę. Społeczeństwo Indii jest społeczeństwem bardzo młodym - średnia wieku wynosi 26,2 roku (25,6 mężczyźni; 26,9 kobiety). W przedziale wiekowym 0-14 lat mieści się 29,7\% społeczeństwa, w przedziale 15-64 lata, a więc w wieku produkcyjnym, $64,9 \%$, a powyżej 65 roku życia zaledwie $5,5 \% .{ }^{77}$ Należy przy tym podkreślić, że w społeczeństwie Indii systematycznie wzrasta liczba ludzi umiejących czytać i pisać, a więc takich, którzy zetknęli się ze szkolnictwem. Szacuje się, że w 2011 roku umiało

${ }^{71}$ Indie ogłaszaja miliardowy program inwestycji publicznych, „Gazeta Wyborcza” 18 stycznia 2012.

72 Z. Zarazik, Kapitał $w$ Indiach najpierw dla gospodarki potem dla banków, Obserwator finansowy. pl, 29 kwietnia 2012, http://www.obserwatorfinansow.pl/forma/analizy/kapital-w-indiach-najpierw -dla-gospodarki-potem-dla-bankow

73 T. Cukiernik, op.cit.

74 Więcej patrz przypis 56.

75 Government of India, Ministry of Home Affairs, Office of the Register General \& Census Commissioner, Provisional Population Total: India: Census 2011, http://www.censusindia.gov.in/2011prov-results/indiaatglance.html

76 Ibidem, s. 38.

77 Central Intelligence Agency, The World Fact Book 2011, India, https://www.cia.gov/library/ publications/the-world-factbook/geos/in.html 
czytać i pisać 74,04\% społeczeństwa (778 454120 osób) tego kraju. ${ }^{78}$ Wprawdzie Indie nie osiągnęły jeszcze średniej światowej - według UNESCO w 2009 roku średnia dla całego świata wynosiła $83,7 \%{ }^{79}$ - ale i tak osiągnęły znaczny postęp, gdyż na początku XX wieku wskaźnik ten wynosił $64,8 \%{ }^{80}$ Wielkość populacji Indii i jej młody wiek sprawiają, że kraj ten dysponuje znaczą grupą ludzi w wieku produkcyjnym. Z jednej strony Indie są w stanie zaspokoić zapotrzebowanie na pracowników na swoim rynku pracy, z drugiej zaś sprzyja to poszukiwaniu pracy za granicą. W przypadku Indii liczbę emigrantów zarobkowych dla 2010 roku szacowano na 11375500 ludzi, co stawiało ten kraj na drugim miejscu po Meksyku jako źródło emigrantów. Różnica w liczbie emigrantów między tymi dwoma krajami nie była duża, gdyż meksykańską emigrację w 2010 roku szacowano na 11859 200, czyli różnica wynosiła $483700 .{ }^{81}$

Hinduska emigracja ma różne kierunki. Najczęściej wybierane kraje emigracji to: Zjednoczone Emiraty Arabskie, Stany Zjednoczone, Arabia Saudyjska, Bangladesz, Nepal, Wielka Brytania, Kanada, Oman, Kuwejt i Sri Lanka. ${ }^{82}$ Najistotniejsze jest jednak to, że ci emigranci są źródłem pieniędzy napływających do Indii, przy czym sumy te mają tendencje wzrostowe. W 2009 roku było to 49,6 mld dol., w 2010 roku - 55 mld dol., a w 2011 roku - 57 mld dol., ${ }^{83}$ podczas gdy w 2010 roku PKB Indii wyniósł $1538 \mathrm{mld}$ dol. (na 2011 rok prognozowano $1704 \mathrm{mld}$ dol.). ${ }^{84}$

Indyjska emigracja ma także inny, niezwykle istotny wymiar, który tylko częściowo da się przeliczyć na pieniądze. Często na emigrację decydują się ludzie młodzi, bardzo dobrze wykształceni, szczególnie z branży IT. Przy czym, w większości

78 Wskaźnik ten bardzo różnie prezentuje się na poziomie poszczególnych stanów. Najniższy poziom analfabetyzmu w społeczeństwie notowany jest w stanie Kerala, gdzie 93,9\% ludzi umie czytać i pisać. Natomiast w stanie Bihar wskaźnik ten wynosi jedynie 63,8\%. TheOnlineGK, Literacy Rate In India State: Census 2011, http://theonlinegk.wordpress.com/2011/04/02/literacy-rate-in-indian-state-census-2011/; V. Kumar, Census 2011: Population Pegged at 1,210.2 Million, „The Hindu” March 31, 2011, http://www. thehindu.com/news/national/article1587153.ece?homepage=true

79 UNESCO, Institute of Statistics, Reports, Regional Literacy Rates for Youths (15-24) and Adults (15+), http://stats.uis.unesco.org/unesco/TableViewer/tableView.aspx?ReportId=201

80 Population Rise Slows, Literacy Grows, Girls Vanish, „The Times of India” April 1, 2011, http://articles. timesofindia.indiatimes.com/2011-04-01/india/29369852_1_india-growth-story-gender-bias-population

81 World Bank, The Migration and Remittance Factbook 2011, Mexico, http://siteresources.worldbank. org/INTPROSPECTS/Resources/334934-1199807908806/Mexico.pdf

82 World Bank, The Migration and Remittance Factbook 2011, India, http://siteresources.worldbank. org/INTPROSPECTS/Resources/334934-1199807908806/India.pdf

83 The World Bank, Migration and Remittances Factbook 2011, Washington 2011, s. 13, http://data. worldbank.org/data-catalog/migration-and-remittances; Rema Nagarajan, Indians No. 2 in Emigrating, Top in Sending Money Home, ,Times of India” December 6, 2010, http://articles.timesofindia.indiatimes. com/2010-12-06/india/28215922_1_migration-and-remittances-factbook-countries-flows; Hindusi gotowi do najazdu na Europę. Przyślą każdą liczbę ludzi, „Gazeta Wyborcza” 19 stycznia 2012.

84 International Monetary Fund, Report for Selected Countries and Subjects, http://www.imf.org/ external/pubs/ft/weo/2011/01/weodata/weorept.aspx?sy=2008\&ey=2011\&scsm=1\&ssd=1\&sort=count ry\&ds $=. \& b r=1 \& c=534 \& s=$ NGDPD $\% 2$ CNGDPDPC $\% 2$ CPPPGDP\%2CPPPPC\%2CLP\&grp=0\&a $=\& p r$. $\mathrm{x}=49$ \&pr. $\mathrm{y}=13$ 
przypadków, jest to emigracja tymczasowa „za pracą”. Po spędzeniu kilku lat za granicą ludzie ci wracają do kraju, a ich powrót przynosi trojakie korzyści. Po pierwsze, szczególnie z branży IT, zakładają i z powodzeniem prowadzą własne firmy tej branży. Po drugie, kontynuują lub podejmują współpracę z firmami zagranicznymi, będąc pośrednikami między indyjskim a zagranicznymi rynkami. Po trzecie, wyjeżdżający i z powodzeniem pracujący poza granicami Hindusi wyrabiają dobrą opinię o pracownikach z tego kraju, co sprzyja zatrudnianiu kolejnych. Wpływa to także korzystnie na kreowanie pozytywnego wizerunku Indii jako kraju posiadającego wykształconych, zdolnych i sumiennie pracujących wysokiej klasy specjalistów. ${ }^{85}$

Czynnik ludnościowy ma w Indiach jeszcze jedno olbrzymie znaczenie z punktu widzenia przeciwdziałania kryzysowi. Opublikowane dane wskazują, że gospodarkę Indii napędza rynek wewnętrzny (w 65\%), podczas gdy w Chinach odpowiada on tylko za $42 \%$ PKB. $^{86}$

Biorąc pod uwagę te wszystkie uwarunkowania, można stwierdzić, że Indie mają szanse na relatywnie łatwe i bezbolesne przejście przez światowy kryzys ekonomiczny. Trzeba jednak przy tym przyjąć, że modelu indyjskiego nie da się wprost zastosować w Stanach Zjednoczonych czy w krajach Unii Europejskiej. Gospodarka Indii, pomimo przeprowadzanych reform, w znacznym stopniu jest kontrolowana przez instytucje państwowe, nie ma całkowicie otwartego rynku, a w przypadku sektora bankowego ${ }^{87}$ około $70 \%$ całego rynku usług finansowych znajduje się pod kontrolą państwa. Trzeba także wziąć pod uwagę poziom życia w Indiach znajdujący się w zupełnie innym stadium niż w państwach europejskich czy w Stanach Zjednoczonych, co umożliwia wiele działań, na które nie byłoby przyzwolenia w strefie euroatlantyckiej - można tu wskazać chociażby na kwestie warunków pracy (np. zatrudnianie dzieci) czy też ochrony środowiska. Dlatego też większość analityków z umiarkowanym optymizmem patrzy na przyszłość gospodarczą Indii. Tym, co może się okazać dużo większym problemem do przezwyciężenia, jest korupcja ${ }^{88}$ - w 2011 roku Indie zajmowały 95 pozycję na liczącej 183 państwa liście skorumpowanych krajów. ${ }^{89}$

85 D. Naujoks, Emigration, Immigration, and Diaspora Relations in India, Migration Information Source, October 2009, http://www.migrationinformation.org/Profiles/display.cfm?id=745\#8

${ }^{86}$ M.A. Kolka, H.S. Tuszyński, Indie - przyszły gigant gospodarki światowej, Global Economy, http:// www.globaleconomy.pl/content/view/1844/27

87 Więcej na temat systemu bankowego w Indiach patrz: G.H. Deolalkar, The Indian Banking Sector. On the Road to Progress, http://aric.adb.org/pdf/external/financial_market/India/india_bnk.pdf

88 Więcej na temat zjawiska korupcji w Indiach patrz: Centre for Media Studies, India Corruption Study: 2010. Is the Scenario Changing?, CMS Research House, New Delhi 2011, http://www.cmsindia. org/India\%20Corruption\%20Study\%202010.pdf

$89 \mathrm{http}: / /$ www.transparency.org/country\#IND 
Niedawno wyszła na jaw kolejna afera, a dotycząca górnictwa węgla kamiennego. Według ostrożnych danych ${ }^{90}$ Indie straciły ponad 33 mld dol. w w latach 2004-2009 z powodu zaniżania wysokości opłat za prawo do wydobywania węgla kamiennego. ${ }^{91}$ Tylko nieco mniejszy kaliber miała afera korupcyjna dotycząca licencji na telefonię komórkową. Stu dwudziestu dwóm operatorom, którzy otrzymali koncesje po styczniu 2008 roku, odebrano je, gdyż zostały przyznane nielegalnie. Szacuje się, że straty skarbu państwa z tego tytułu wyniosły między 12,8 a 40 mld dol. ${ }^{92}$ A dzieje się tak, mimo że władze kraju cały czas deklarują walkę z korupcją. ${ }^{93}$

\section{India's economy during world economic crisis: perspectives for the future}

The world economy is in serious crisis for a few years now. First signs of the crisis were noticed in 2006 when the real estate market slump begun, followed by crisis in banking, car manufacturing and other sectors. Some states suffered from recession or economic slow down and the unemployment rates have gone up. Although the crisis was global, it affected different countries in different ways. To be in crisis meant something else for the United States, Japan or EU member states. In this context, much attention was drawn to the fast growing economies as China or India, whose economy grew in last 10 years by up to $9 \%$ annually and suffered comparatively little due to the crisis. What were the mechanisms the protected India's economy from the crisis? Several factors were responsible for that, including active state policy, anti-crisis packages, investments on internal and foreign markets, and huge internal market.

\footnotetext{
90 Niektóre źródła mówiły nawet o 190 mld dol.

91 J. Giziński, Korupcyjna afera weglowa wstrząsnęła Indiami, „Rzeczpospolita” 30 sierpnia 2012; Afera korupcyjna w Indiach, „Rzeczpospolita” 18-19 sierpnia 2012.

92 Indie: mniej sieci komórkowych. Zniknie 122 operatorów, Polskie Radio, 2 lutego 2012, http://www. polskieradio.pl/5/3/Artykul/529393,Indie-mniej-sieci-komorkowych-Zniknie-122-operatorow

93 S.A. Niewiński, Władze Indii wypowiedziały wojnę korupcji, Centrum Studiów Polska-Azja, 16 marca 2010, http://www.polska-azja.pl/2010/03/16/wladze-indii-wypowiedzialy-wojne-korupcji/
} 


\section{Экономика Индии в условиях мирового экономического кризиса. Перспективы на будущее}

Последние несколько лет мировая экономика переживает один из серьезнейших кризисов, которого первые симптомы были видны в 2006 году. Началом стало значительное падение цен на недвижимость, затем пострадали банковский сектор и автотракторная отрасль, а дальше и другие отрасли промышленности. Многие страны пережили спад или замедление темпов экономического роста, значительно повысился уровень безработицы. Тем не менее, несмотря на свой глобальный характер, экономический кризис затронул в разной степени разные страны. Иначе ощутили его США, Япония или государства-члены Европейского Союза. В связи с этим, значительный интерес вызывает вопрос влияния кризиса на страны характеризующиеся быстрым экономическим ростом, как Китай. То же самое относится и к Индии, которая в последнем десятилетии достигла экономического роста на уровне 9\% в год, и несмотря на глобальный экономический кризис, удерживает высокий показатель в этой сфере. Это приводит к вопросу о механизмах, которые защищают Индию от попадания в экономический кризис. Можно указывать на такие факторы, как участие государства в экономике, антикризисные меры, инвестиции на внутреннем рынке и за рубежом, а также большой внутренний рынок. 